Journal of Teacher Education for Sustainability, vol. 22, no. 1, pp. 21-36, 2020

\title{
Promoting Sustainable Social Emotional Learning at School through Relationship-Centered Learning Environment, Teaching Methods and Formative Assessment
}

\author{
Marco Ferreira \\ Instituto Superior de Educação e Ciências, ISEC Lisboa, Lisbon, Portugal \\ Baiba Martinsone \\ University of Latvia, Riga, Latvia \\ Sanela Talić \\ Institute for Research and Development (UTRIP), Borovnica, Slovenia
}

\begin{abstract}
How to promote social emotional learning (SEL) at school depends largely on teachers. Mostly teachers implement specific programs, but they have difficulties in incorporating SEL into the regular curriculum. The main aim of the paper is to present the conceptual model of sustainable integration of SEL into everyday teaching practices in every subject. This approach has been developed in the project "Learning to Be: Development of Practices and Methodologies for Assessing Social, Emotional and Health Skills within Education Systems". This initiative is based on the premise that the assessment of learning at school should go beyond grading students' knowledge and should include practices for observing young people's personal growth, social skills, attitudes and other general competences. The novelty of this conceptual approach is associated with integrating SEL standards, formative assessment and classroom instruction into a single sustainability-oriented model. The relationship between SEL standards (ISBE, 2003) and formative assessment strategies established by Wiliam (2011) is described, providing a detailed description of specific classroom activities. The objective of this approach is, therefore, towards building emotionally strong and flexible individuals who can deal with complex challenges through prosocial behavior that encourages human prospering and the attainment of the United Nations' Sustainable Development Goals.
\end{abstract}

Key words: social emotional learning, teaching methods, sustainable teaching practices, SEL standards, formative assessment 


\section{Introduction}

Social emotional learning (SEL) is the process by which each student develops their capacity to integrate thought, emotion and behavior to achieve and accomplish important social tasks. In this sense, students develop skills that allow them to recognize, express and manage emotions, build healthy relationships, establish positive goals and respond to personal and social needs (CASEL, 2003; Lemerise \& Arsenio, 2000). In this way, social emotional learning fosters the use of various cognitive and interpersonal skills to achieve relevant goals, both socially and developmentally (Zins et al., 2004). Particularly relevant to the several competences of social emotional learning are self-awareness, self-management, social awareness, relationship skills and responsible decision-making (CASEL, 2005). These competences will foster better social adjustment and academic performance reflected in more interactive behaviors, lower behavioral problems and less emotional stress (Greenberg et al., 2003). Social emotional learning enables students to become more responsible, empathic and productive, promoting a dynamic participation in society and citizenship (Lemerise \& Arsenio, 2000).

The need for resilient and adaptive individuals for rapidly changing environments is becoming increasingly important. Recent research has demonstrated that students need social awareness and emotional connectedness in order to learn effectively. The $21^{\text {st }}$ century poses many new challenges to younger generation. In the face of these challenges, the World Health Organization's (2015) report on mental health states that the incidence of mental health problems with younger generation is increasing rapidly. Along the same line of thought, the UNESCO (2019) is poised to widely disseminate programs for SEL that will have the potential to influence the development of the next generation of global citizens.

We believe that teachers have the primary role in promoting SEL and mental health at school, but many of them have difficulties in incorporating SEL into the regular curriculum. The new developers of programs also receive insufficient pre-service preparation and ongoing support to help them develop the necessary attitudes and skills to carry out their responsibilities successfully. This is true with new approaches to literacy, school climate and character education, as well as the area of SEL (Elias et al., 2003).

In this paper, some teaching methods will be detailed, connecting Illinois State Board of Education SEL standards with Wiliam's formative assessment strategies. The goal is to outline in a meaningful and understandable way, with specific examples, the main principles for a sustainable practice of SEL at schools, providing information for assessing students' social and emotional competences in class through a relationshipcentered learning environment.

Like academic skills, social emotional competences can be learned and practiced through participation in meaningful activities in and outside the classroom (Elias et al., 1997), fostering students' progressive improvement and integration, helping them respond to more complex situations in academic, social, citizenship and health terms (CASEL, 2003). Promoting social emotional learning with students in the classroom involves behavior modelling and the teacher must provide opportunities inside the classroom for students to apply and expand those skills.

Illinois SEL standards describe the content and skills for students in several grades regarding social emotional learning. Each standard includes five benchmark levels that describe what students should know and be able to do in early elementary, late elementary, middle/junior high, early high school, and late high school (ISBE, 2003). Crossing these 
SEL standards with Wiliam's formative assessment strategies means, among others, understanding learning intentions, eliciting evidence of learning and providing meaningful feedback. In other words, it means to respond to Why, What and How of using assessment to improve learning (Wiliam, 2011).

In 2015, 195 nations agreed that they could change the world for the better. The UN's Sustainable Development Goals aim at ending poverty, protecting the planet and ensuring prosperity for everyone by 2030 (United Nations, 2015). Schools are at the frontline to the achievement of these goals, and SEL is a key to building both emotional and cognitive intelligence in learners and can also play a pivotal role in achieving sustainable societies.

\section{Principles for a Sustainable Practice of SEL at Schools}

Schools are social places and learning is, in the same way, a social process (Vygotsky, 1962). In fact, students do not learn alone, but mainly in a collaborative way with teachers, in contacts/discussions with peers and with the encouragement of their families (Machado \& César, 2012). Since social and emotional factors affect the form and time of learning, schools must concentrate on these features to benefit all students (Elias et al., 1997). Emotions can facilitate or block learning and, in the end, student success (Schutz \& Pekrun, 2007). Teachers' attitudes, motivation, and willingness to participate in continuous professional development courses related to SEL may also significantly influence an effective application of SEL activities (Martinsone \& Vilcina, 2017).

Nowadays, one of the challenges faced by the school is to assist a diversity of students not only from a cultural point of view, but also from a cognitive and motivational point of view (Ferreira, 2017). In a classroom, there are students committed and involved with the activities, while others require more support demonstrating less involvement in the academic tasks. On the other hand, if issues related to indiscipline, lack of commitment, and other negligence behaviors limit success at school and lead to failure (Zins et al., 2004), it becomes critical to respond to this diversity that interferes with the students' ability to engage at school and limit their development.

Although, historically, schools have sought to integrate into their objectives areas such as moral character, citizenship and social responsibility, this question has often been thought of by schools in a fragmented way, either as an end or as a specific contribution to develop health, safety or citizenship. In fact, only at the beginning of this century there has been an increasing interest in the areas of students' social and emotional learning (Zins et al., 2004). The idea of education for sustainable development (ESD) has been clearly presented by Fischer et al. (2015). In order to reach more holistic ESD, the focus should be not simply on teaching a particular course content, but on the incorporation of different approaches and strategies, for example, for indirect provision of social emotional learning. ESD corresponds not only to avoiding the environmental crisis (Shallcross, 2003), but also, as we see now, to overtaking the social crisis and its emotional aspects. The concept of ESD is inclusive itself.

Some key principles are highlighted in the literature in order to promote successful and sustainable practice of SEL at schools. SEL practices tend to occur within supportive contexts, acknowledging features of a broader community context (CASEL, 2005; Elbertson, Brackett, \& Weissberg, 2010); to extend SEL beyond the classroom, finding time to implement SEL activities sufficiently and efficiently throughout the school (Durlak 
et al., 2011); to ensure enough staff support and training (CASEL, 2005; Denham, 2017); and finally, to use data to inform decision making, calling upon tools to assess students' outcomes, and tools to assess and support SEL implementation practices (CASEL, 2005; Domitrovich \& Greenberg, 2000).

SEL intervention at school involves instructional, modelling and practical application activities that can be implemented and supported by administrators and conducted by teachers. It must also be embedded in the curriculum of the disciplines and be complemented by formal and informal interactions between students and teachers inside and outside of the classroom. Schools will accomplish better its educational mission if they integrate SEL into the overall educational experience of students, maximizing their potential and promoting future success both in personal and professional life (Elias et al., 1997; Fernández-Berrocal \& Ruiz, 2008). SEL fosters a positive school climate that is participatory and beneficial for learning and should be considered in strategic plans, curriculum choices, school policies and practices.

\section{SEL and Teachers}

In general, teachers are consensual when considering that the school has the purpose of equipping students with social and emotional competences that, along with cognitive competences, enhance their integral development and, consequently, promote their academic success and prepare them for adult life. However, the majority of teachers acknowledged that in their school reality, despite the implicit appreciation of this purpose, the absence of a national curriculum guidance on social emotional development made the approach of each school variable and largely dependent on their own interests and motivations (Elliott \& Mihalic, 2004). Teachers will be most instrumental to inculcate human values and improve value education, because teachers play a critical role as guides or learning facilitators (Ghorbani, Jafari, \& Sharifian, 2018).

Teachers can promote social emotional skills through their own interpersonal interactions with students and support their day-to-day academic activities emphasizing social and emotional skills. Nevertheless, it depends on determination and interest of each teacher on SEL. Students' interactions with adults and classmates will develop SEL competences as they also influence the student's relationship with the teacher and colleagues, making positive climate inside the classroom (Elias et al., 1997). Besides, social emotional learning at schools can proactively defend teachers against teacher burn-out, and these activities can facilitate the perceived self-efficacy of teachers, which is a significant aspect of the teachers' role (Martinsone, 2016).

There are so many and simple activities that teachers can use inside the classroom in order to adhere to SEL without compromising the overall curriculum, for example, activities where students can control themselves, understand the perspective of others, make wise choices about personal and social decisions, develop confidence, persistence and empathy, activities where students decrease emotional distress and enhance a greater commitment with the school. In their study, Ulavere and Veisson (2015) found that teachers and parents of preschool children considered honesty, health, helpfulness, cooperation ability, tolerance, trust, sense of duty and independence as the most important values to be taught to children. These skills help students establish and maintain healthy and rewarding relationships, and behave according to social norms. They also involve clear communication, careful listening, cooperation, resilience to inadequate social pres- 
sure, flexibility in the resolution of conflicts. It can also be done without specific SEL lessons. Since social and emotional skills play an important role in the development, it is imperative that these be integrated into mainstream education for holistic development of all learners (Mahoney, Durlak, \& Weissberg, 2018).

Teachers do have an important role in supporting the requisite sustainability learning process since their principal role is no longer simply to transmit knowledge to students. Bell (2016) argues that most discussions of the $21^{\text {st }}$ century education are not targeted at transforming but rather at servicing the global economy. It emphasizes the importance to address such essential skills as social and emotional ones to provide sustainable education and even more - sustainable personality development for both students and educators.

Teaching practices such as cooperative learning, classroom discussions, self-assessment and self-reflection activities, balanced instruction, academic press and expectations, and competence building are very emphasized in the literature and should be carried out during everyday teaching routines (CASEL, 2012; Druskat \& Wolff, 2015; Goldstein et al., 2011; Savitz-Romer \& Bouffard, 2012). On the other hand, there is research that shows to successfully promote SEL, it is not enough to enhance teachers' knowledge of SEL alone. Teachers' own social and emotional competence and wellbeing appear to play a crucial role. Teachers with higher social emotional competence organize their classrooms and provide emotional and instructional support in ways that are associated with a high-quality classroom climate (Jennings \& Greenberg, 2009). These authors recommend that SEL interventions must consider teachers' own SEL competence and wellbeing to help them implement SEL effectively. In their study, Jennings and Greenberg (2009) highlighted that good relations between teacher and students and among students themselves, thus a trustful learning environment, are a good foundation from which to learn to deal with challenging situations in a classroom. They also agree that sharing experiences and solving problems together help teachers tackle challenging situations at school.

Several studies show consistently that warm classroom environments and positive teacher-student relationships promote both academic learning and social and emotional competences (Gest, Welsh, \& Domitrovich, 2005; Klem \& Connell, 2004). Consequently, teachers, on the one hand, need to know how to explicitly teach social and emotional skills and, on the other hand, need the knowledge, dispositions and skills for creating a safe and supportive classroom environment. Durlak and colleagues (2011) also showed in their study that teachers who understood child and adolescent development were better able to design and carry out learning experiences in ways that support social, emotional and academic competence.

Nowadays, teachers' performance quality and evaluation are under an intense scrutiny (European Commission, 2015; OECD, 2013). The past two decades have witnessed intense work to develop successful programs to improve the quality of teacher preparation and teacher professional development. All over Europe, new policies have delineated professional standards, improved teacher preparation and certification requirements, and increased investments in programs that provide mentoring to new teachers and support teachers' professional development. Explicitly promoting SEL in pre-service teacher education is an important step. However, several challenges remain.

There are so many variables referenced in the literature that involve SEL and teachers, that we have just left here only some topics that could influence the relationship between teachers and SEL implementation practices in the classroom. 


\section{SEL Standards and Formative Assessment}

Standards on student social and emotional development were developed and accepted by Illinois State Board of Education (ISBE) in December 2004, after their inclusion in 2003 Illinois Children's Mental Health Act. Illinois SEL standards encompass CASEL's (2003) five following core skills areas: Self-awareness - related to the assessment of one's feelings, interests, values, and strengths and valuing self-confidence; Self-management - associated with one's resilience toward stress and determination in overcoming difficulties, also related to monitoring progress toward personal goals; Social awareness being able to take the perspective of and empathize with others, recognizing and valuing individual and group diversity, also considering family, school and community resources; Relationship skills - sustaining healthy and gratifying relationships, resisting inappropriate social pressure and resolving interpersonal conflict; Responsible decision-making making decisions based on ethical standards and social norms, respect for others, applying decision-making skills with safety concerns, valuing the well-being of the overall community (CASEL, 2003). In order to address children's social emotional needs systematically, education of wider community is needed (Elias et al., 2003). Since the adoption of Illinois SEL standards, Illinois was a model for fostering the implementation of evidence-based and integrated SEL programming (O'Brien \& Resnik, 2009). State agencies and schools developed new relations in order to address the SEL standards throughout Illinois State. The focus was to expand evidence-based information about SEL practice, disseminating SEL to educational communities, such as associations and policy makers. ISBE and CASEL spread the word that made possible, on the one hand, to develop social emotional learning standards inside the classroom and, on the other hand, to incorporate SEL within all learning subjects (O’Brien \& Resnik, 2009). Illinois SEL standards (2003) provide a comprehensive guide to students' SEL educational objectives, helping them monitor their evolution, and providing to the teachers a new approach to teaching and learning process. The SEL standards describe what students should know, understand and be able to do in order to accomplish the three following goals: (1) to develop selfawareness and self-management skills to achieve school and life success; (2) to use social-awareness and interpersonal skills to establish and maintain positive relationships; (3) to demonstrate decision-making skills and responsible behaviors in personal, school and community context (O’Brien \& Resnik, 2009).

Within the SEL standards, more detailed learning targets are identified. They are benchmarks that specify SEL knowledge and skills at the five grade-level, taking into consideration students' age. From lower grade-levels to upper grade-levels, benchmarks will increase in terms of involvedness and complexity. Learning standards and benchmarks are also detailed as performance descriptors in order to help teachers design syllabi and select classroom activities. This specification also brings some helpful directions in assessing students' achievement of social and emotional skills (Payton et al., 2008). Social and emotional skills, like any other learning area, should be assessed at school in order to support students' learning (Devaney, O’Brien, Resnik, Keister, \& Weissberg, 2006; O'Brien \& Resnik, 2009). Relevant assessment practices could help students monitor their own learning, receive on-time feedback about their evolution and inform the teachers about teaching practices that should be applied in the future. Therefore, we consider relevant to develop a learning-friendly classroom environment, where the major goal is to promote supportive relationships, which will lead to meaningful learning, concomitantly promoting academic success. 
Formative assessment methods and feedback imply students' involvement and a continuous alliance between the student and teacher. Feedback is, thus, understood as a key element of the student learning process and student self-regulation (Carless, 2006; Nicol \& Macfarlane, 2006). Teachers' feedback on student performance should be timely so that it can be useful not only for the present but especially for the future. In addition, students must be aware of the assessment criteria, and, thus, feedback needs to be presented in a way that allows them to recognize their level of performance. It should also indicate clearly how to improve students' learning and to encourage them to reflect on the feedback that has been provided (Sendziuk, 2010). Thus, it is important to put into practice assessment methods that require an active involvement of the students and a continuous analysis of the appropriateness and coherence of the methods applied.

Formative assessment has the aim to improve teacher practice and ultimately improve student learning. Systematic assessment procedures can identify students who are not making as much progress as expected. In this way, formative assessment can be considered a key component of well-regulated learning environments. From this perspective, the task of the teacher is not necessarily to teach, but rather to create/plan situations, in which students learn effectively (Black \& Wiliam, 2004). This idea is very appealing and brings to the debate a new conception of teaching and assessment.

Based on the work developed in the last three decades, Wiliam and colleagues developed for the first time the five key strategies that supported the implementation of effective formative assessment (Leahy et al., 2005). Each of the five strategies get a chapter in Wiliam's book "Embedding Formative Assessment" (2011), and these strategies will support our next section, where we will suggest their connection with SEL standards. These strategies are the core to successful formative assessment practice and are expressed as follows:

1. Clarifying, sharing and understanding learning intentions and criteria for success - students' systematic understanding about their classroom experience.

2. Engineering effective classroom discussions, activities and learning tasks that elicit evidence of learning - developing classroom instructional strategies that potentiate the measurement of success.

3. Providing feedback that moves learning forward - providing the students with the information for better comprehension of problems and solutions.

4. Activating learners as instructional resources for one another - involving students in discussions and team work that can help improve their own learning.

5. Activating learners as owners of their own learning - teaching students to monitor and regulate their learning (Wiliam, 2011).

These strategies allow both the collection of meaningful information promoting teaching and learning constant adjustments for teachers and adaptation of their work to put the learning back on track for students. In this way, we have found an excellent opportunity to connect Illinois SEL standards with Formative Assessment strategies developed by Wiliam. Formative assessment encourages teachers to adjust their teaching practice that is the essence to consider formative assessment for our purpose. Combining SEL with these everyday teaching procedures can constitute a powerful tool for teachers and a meaningful way to promote SEL in classes. Combining formative assessment practices with the development of SEL competences in the classroom will allow teachers to reflect on their practice and make small steps in improving students' social and emotional competences. More specifically, we intend to clarify what we want students to learn 
(SEL standards) and then use assessment to find out if they are learning what we want them to learn (Wiliam's five formative assessment strategies). In addition, we know that assessment needs to be focused on long-term changes in students' capabilities rather than how well they perform in a specific learning task. However, this could be the first step to involve teachers in changing their daily teaching practices. We also believe that this can constitute an opportunity for teachers to increase their teaching/assessment skill repertoire and to include in the classroom opportunities for developing student social and emotional competences.

In the next section, we will outline the connection for a sustainable and successful practice of SEL inside the classroom, building bonds and ties with Wiliam's formative assessment strategies. Our goal is to make this link very understandable in order to add value to teachers' daily routines, providing simple strategies and activities for assessing students' social emotional competences in class. In order to achieve this goal, examples of some teaching methods will be introduced.

\section{Teaching Methods - Connecting SEL Goals according to Illinois State Board of Education Standards and Wiliam's Formative Assessment Strategies}

This section will be devoted to illustrating the implementation of instructional teaching methods through the integration of SEL goals and formative assessment. Throughout these examples, we will emphasize evidence of students' learning. Teachers' role is both to recognize evidence of students' learning (to address students' individual needs and development) and to provide a meaningful context for learning. A key element of teacher's action is the provision of positive and relevant feedback. For example: "Yes, you have answered all questions and let's ask the opinion of others". Yes is the positive approval; You have answered corresponds to what specifically is well done; And joins together confirmation and the direction of further development; Let's ask provides a clear direction for further development (on what I will work together with my teacher).

The activity in Table 1 is based on the first SEL goal that includes intrapersonal competence and self-regulation, which is the ability to accurately recognize and regulate one's own emotions, thoughts and values, and how they influence behavior.

\section{Table 1}

Connecting the First Goal of SEL Learning Standard - Development of Self-awareness and Self-management-and Formative Assessment Strategies through the Activity "Who am I Right Now?”

\begin{tabular}{|c|c|}
\hline $1^{\text {st }}$ goal of SEL standard & To develop self-awareness and self-management. \\
\hline Main activity & Who am I right now? \\
\hline \multirow[t]{5}{*}{ Specific activities } & Observation and self-evaluation of social and emotional skills. \\
\hline & $\begin{array}{l}\text { Creating one's own portfolio. Working in pairs in order to monitor } \\
\text { their personal development. }\end{array}$ \\
\hline & Positive and specific feedback. \\
\hline & Interviewing classmate; how my colleague sees me? \\
\hline & Filling self-reflection cards. \\
\hline
\end{tabular}


Continuation of Table 1

Wiliam's formative assessment strategies
Clarifying, sharing, and understanding learning intentions and criteria for success.

Engineering effective classroom discussions, activities, and learning tasks that elicit evidence of learning.

Providing feedback that moves learning forward.

Activating learners as instructional resources for one another.

Activating learners as owners of their own learning.

The second goal corresponds to social awareness, which includes development of perspective-taking, empathy and tolerance. Table 2 includes activities for providing context for the development of social awareness.

Table 2

Connecting the Second Goal of SEL Learning Standard - Development of Social Awareness - and Formative Assessment Strategies through the Activity "How do I See Others?"

\begin{tabular}{|c|c|}
\hline $2^{\text {nd }}$ goal of SEL standard & To develop social awareness. \\
\hline Main activity & How do I see others? \\
\hline \multirow[t]{10}{*}{ Specific activities } & Observation of feelings and perspectives of others. \\
\hline & How can I show kindness towards others? \\
\hline & What is empathy? \\
\hline & Setting learning intentions and criteria for success. \\
\hline & $\begin{array}{l}\text { ABCD cards, mini whiteboards, exit passes. } \\
\text { How are my social skills? }\end{array}$ \\
\hline & $\begin{array}{l}\text { Starting to write a journal. Feedback from teacher, parents or the } \\
\text { best friend. }\end{array}$ \\
\hline & $\begin{array}{l}\text { Building up a poster on skills learned, presenting it to their class- } \\
\text { mates. }\end{array}$ \\
\hline & $\begin{array}{l}\text { Assessing the work of the colleagues (e.g., how many critical aspects } \\
\text { of social perspective are highlighted?) }\end{array}$ \\
\hline & $\begin{array}{l}\text { Two stars and a wish - two areas where the work excelled; an } \\
\text { area where there could be some improvement. }\end{array}$ \\
\hline & Future steps - self-evaluation; evidence of learning. \\
\hline \multirow[t]{5}{*}{$\begin{array}{l}\text { Wiliam's formative } \\
\text { assessment strategies }\end{array}$} & $\begin{array}{l}\text { Clarifying, sharing and understanding learning intentions and } \\
\text { criteria for success. }\end{array}$ \\
\hline & $\begin{array}{l}\text { Engineering effective classroom discussions, activities and learning } \\
\text { tasks that elicit evidence of learning. }\end{array}$ \\
\hline & Providing feedback that moves learning forward. \\
\hline & Activating learners as instructional resources for one another. \\
\hline & Activating learners as owners of their own learning. \\
\hline
\end{tabular}

Social interaction provides a good foundation for learning. The ability to establish and maintain healthy and rewarding relationships is crucial for children's global development.

Table 3 contains activities on how to develop students' relationship skills through everyday teaching routines. 
Marco Ferreira, Baiba Martinsone, and Sanela Talić

Table 3

Connecting the Third Goal of SEL Learning Standard - Development of Relationship Skills - and Formative Assessment Strategies through the Activity "How am I with Others?"

\begin{tabular}{|c|c|}
\hline $3^{\text {rd }}$ goal of SEL standard & To develop relationship skills. \\
\hline Main activity & How am I with others? \\
\hline \multirow[t]{4}{*}{ Specific activities } & $\begin{array}{l}\text { Essay compilation of pictures from magazines, the Internet, repre- } \\
\text { senting friendship, healthy relationships and effective communi- } \\
\text { cation. }\end{array}$ \\
\hline & $\begin{array}{l}\text { Pyramid 3-2-1: } \\
3 \text { things they have learned about their relationship skills, } \\
2 \text { things they are proud of (connected to relationship skills), } \\
1 \text { skill they should develop. }\end{array}$ \\
\hline & $\begin{array}{l}\text { Writing journal (feedback from teacher). } \\
\text { Tweet/retweet (on relationship skills). }\end{array}$ \\
\hline & $\begin{array}{l}\text { Relationship skill inventory (classmates provide feedback). } \\
\text { TAG feedback - A classmate tells something about their relation- } \\
\text { ship skillsto give a suggestion for higher engagement. }\end{array}$ \\
\hline \multirow[t]{4}{*}{$\begin{array}{l}\text { Wiliam's formative } \\
\text { assessment strategies }\end{array}$} & $\begin{array}{l}\text { Clarifying, sharing and understanding learning intentions and } \\
\text { criteria for success. }\end{array}$ \\
\hline & $\begin{array}{l}\text { Engineering effective classroom discussions, activities and learning } \\
\text { tasks that elicit evidence of learning. }\end{array}$ \\
\hline & Providing feedback that moves learning forward. \\
\hline & Activating learners as instructional resources for one another. \\
\hline
\end{tabular}

A constant sharing of feelings, analysis of situations and emotions helps the learners develop independent learning. Active working allows building up active engagement that encourages interaction, the sharing of ideas and teamwork tasks. A problem-based learning is that the learning starts with a problem, a question or scenario, within which several topics of learning can be present.

Table 4 includes activities for the development of responsible decision-making.

Table 4

Connecting the Fourth Goal of SEL Learning Standard - Development of Responsible Decision-Making - and Formative Assessment Strategies through the Activity "Good Choices, Bad Choices!"

\begin{tabular}{ll}
\hline $4^{\text {th }}$ goal of SEL standard & To develop responsible decision-making. \\
\hline Main activity & Good choices, bad choices! \\
\hline Specific activities & $\begin{array}{l}\text { Allow thinking time }- \text { after a question, a pause to allow students } \\
\text { to respond, what does it mean to be responsible? How to link re- } \\
\text { sponsibility to decision making? }\end{array}$ \\
\cline { 2 - 2 }
\end{tabular}

Follow up enquiry - allowing students to probe their reasoning. Students identify choices/decisions they make daily. Listing the possible solutions. Drawing inferences and making deductions.

Play devil's advocate - Using feedback with an alternative point of view and challenge students to think outside the box in problem solving. 
Continuation of Table 4

Think - pair - share - To allow individual thinking time, ask the students to discuss their ideas with classmates to find the best solution, agreeing on contingencies, then share these in the class discussion.

Monitoring and evaluation time - Enable students to judge the value of their choices / decisions. What were the consequences? To develop criteria for judging the value of their own and other's decisions.

Wiliam's formative assessment strategies

Clarifying, sharing and understanding learning intentions and criteria for success.

Engineering effective classroom discussions, activities and learning tasks that elicit evidence of learning.

\begin{tabular}{l}
\hline Providing feedback that moves learning forward. \\
\hline Activating learners as instructional resources for one another. \\
\hline Activating learners as owners of their own learning.
\end{tabular}

It is believed when SEL is embedded in classrooms, problem solving becomes commonplace, diversity is valued and citizenship skills flourish. SEL is developmental. In complexity of the activities, the development, age, diversity and interests of the group should be considered. Social emotional learning occurs across various stages and teachers can have a crucial role with their action inside the classroom, being able to leave an enormous impact on the future of all individuals.

Lately, approaches to SEL have become more focused on teacher training, as well as on the totality of school and classroom learning environments (Taylor et al., 2017). Teacher is considered to be an action researcher (Salite, 2008), and in this particular intervention it is provided both through permanent assessment of children's social and emotional skills (according to SEL standard) and reflection (through provision of reflective learning environment for students and regular self-reflection of teachers).

Taking such systems-wide whole school approach targeted at holistic development of adults and students represents the next phase of SEL future approaches.

\section{Concluding Remarks}

OECD (2018) highlights the vital role of education in developing competences "that enable people to contribute to and benefit from an inclusive and sustainable future... Education needs to aim to do more than prepare young people for the world of work; it needs to equip students with the skills they need to become active, responsible and engaged citizens" (p. 4).

The main idea of promoting social emotional learning at school through relationshipcentered learning environment, teaching methods and formative assessment is that teachers should use evidence of students' learning to adapt teaching to meet students' needs. Tying together teaching methods, SEL goals and formative assessment allows for the clarification of teaching strategies, leads to a better understanding of learning purposes and enables the appearance of evidence of learning. The formative assessment is only fully implemented in the classroom when teachers adapt their pedagogical practices to evidence students' learning. If teachers do not use the evidence to improve the daily routines inside the classroom, they do not perform formative assessment. 
Wiliam's five formative assessment strategies outline the ground of assessment for learning, but teachers are responsible for choosing the activities to implement these strategies. The important thing is that teachers need to adapt any technique to their local context (Wiliam, 2011). This process of contextualization is crucial for adapting teaching practices to students' individual needs. This also creates teacher's ownership, bringing value and responsibility for the teacher. The key requirements for the contextualization must be originated in deep cognitive principles and should be relevant and feasible to teacher's practice. In this way, implementing SEL at school involves knowledge of children development, pedagogical expertise, classroom management, prevention and others.

Social emotional skills allow children to calm themselves, make friends, resolve conflicts respectfully and make ethical and safe choices (O'Brien \& Resnik, 2009). Nowadays, no one denies its importance and the impact that a school can have on the development of responsible citizens, who empathize with others from diverse backgrounds and cultures, who value ethics and human rights, who could make constructive choices about personal behavior and social interactions. It is clear that SEL is completely compatible with the major priorities of today's schools. These include the need to use evidence-based instruction, be safe and drug-free, and promote higher levels of academic achievement for all students. It is important to say that implementing SEL at school will not undermine the core academic subjects, but rather can enhance them. The aim of the paper was to highlight the relevance of the interaction between formative assessment practices with the development of SEL competences in the classroom. They can be easily intertwined, but teaching is all about knowing the conditions under which a method is likely to work. That is why we cannot tell teachers what to do, we just can provide useful information and relevant data that enable them to get new insights and expertise.

Another point that needs to be raised is the challenges that arise from questions concerning the universality of SEL across settings and cultures. As different cultures have different school, family and community contexts, and will have different priorities with respect the competences they want to promote and problems they want to prevent, SEL may not necessarily be the same in all cultures (Weissberg, 2019). Thus, the extent to which SEL programs need to be culture specific to fit the range of recipient student populations across societies must be considered. We also need to know more about the best ways to prepare educators to implement evidence-based SEL programs effectively and engage in data-driven efforts to continuously improve their programs and SEL outcomes (Weissberg, 2019). There are also some other crucial points for promoting social emotional learning according to the principles of education for sustainable development, such as using school-wide interventions, developing capacity of educators and integration of the approach in the policy of all levels (UNESCO, 2014). Following these principles, we could target the aims of the future education through adapting instructional systems to develop students' competences necessary for thriving the world in 2030 (OECD, 2018). This conceptual model for implementing SEL in everyday teaching routines is targeted at embodying the aforementioned principles. 


\section{Acknowledgements}

We are thankful to be part of the team of the EU funded Erasmus+ project key action 3 "Learning to Be: Development of Practices and Methodologies for Assessing Social, Emotional and Health Skills within Education Systems”.

\section{References}

Bell, D. V. J. (2016). Twenty-first century education: Transformative education for sustainability and responsible citizenship. Journal of Teacher Education for Sustainability, 18(1), 48-56. doi: 10.1515/jtes-2016-0004

Black, P. J., \& Wiliam, D. (2004). Classroom assessment is not (necessarily) formative assessment (and vice-versa). In Wilson, M. (Ed.), Towards coherence between classroom assessment and accountability, $103^{\text {rd }}$ Yearbook of the National Society for the Study of Education (part 2) (pp. 20-30). Chicago, IL: University of Chicago Press.

Carless, D. (2006). Differing perceptions in the feedback process. Studies in Higher Education, 31(2), 219-233.

CASEL. (2003). Safe and sound: An educational leader's guide to evidence-based social and emotional learning (SEL) programs. Retrieved from https://casel.org/wp-content/ uploads/2016/01/PDF-16-safe-and-sound.pdf

CASEL. (2005). Safe and sound: An educational leader's guide to evidence-based social and emotional learning programs - Illinois edition. Retrieved from https://casel.org/ safe-and-sound-an-educational-leaders-guide-to-evidence-based-social-andemotional-learning-programs-illinois-edition/

CASEL. (2012). 2013 CASEL guide: Effective social and emotional learning programs: Preschool and elementary school edition. Chicago, IL: Collaborative for Academic, Social, and Emotional Learning.

Denham, S. A. (2017). Assessment of SEL in educational contexts. In Domitrovich, C. E., Durlak, J. A., Weissberg, R. P., \& Gullotta, T. P. (Eds.), Handbook of social and emotional learning: Research and practice (pp. 285-300). New York: The Guilford Press.

Devaney, E., O’Brien, M. U., Resnik, H., Keister, S., \& Weissberg, R. P. (2006). Sustainable school-wide social and emotional learning (SEL): Implementation guide and toolkit. Chicago, IL: Collaborative for Academic, Social, and Emotional Learning.

Domitrovich, C. E., \& Greenberg, M. T. (2000). The study of implementation: Current findings from effective programs that prevent mental disorders in school-aged children. Journal of Educational and Psychological Consultation, 11, 193-221.

Durlak, J. A., Weissberg, R. P., Dymnicki, A. B., Taylor, R. D., \& Schellinger, K. B. (2011). The impact of enhancing students' social and emotional learning: A metaanalysis of school-based universal interventions. Child Development, 82(1), 405432.

Druskat, V. U., \& Wolff, S. B. (2015). Building the emotional intelligence of groups. HBR's 10 must reads on emotional intelligence. Cambridge, MA: Harvard Business Review Press. 
Elbertson, N. A., Brackett, M. A., \& Weissberg M. P. (2010). School-based social and emotional learning programming: Current perspectives. In Hargreaves, A. et al. (Eds.), Second international handbook of education change (pp. 1017-1032). Springer International Handbooks of Education 23.

Elias, M. J., Zins, J. E., Graczyk, P., \& Weissberg, R. P. (2003). Implementation, sustainability, and scaling up of social emotional and academic innovations in public schools. School Psychology Review, 32, 303-319.

Elias, M. J., Zins, J. E., Weissberg, R. P., Frey, K. S., Greenberg, M. T., Haynes, N. M., Kessler, R., Schwab-Stone, M. E., \& Shriver, T. P. (1997). Promoting social and emotional learning: Guidelines for educators. Alexandria, VA: Association for Supervision and Curriculum Development.

Elliot, D. S., \& Mihalic, S. (2004). Issues in disseminating and replicating effective prevention programs. Prevention Science, 5, 47-53.

European Commission. (2015). Strengthening teaching in Europe. New evidence from teachers compiled by Eurydice and CRELL. European Commission. Education and Training.

Fischer, D., Aubrecht, L. E., Bruck, M., Ditges, L., Gathen, L., Jahns, M., Petersmann, M., Rau, J., \& Wellmann, C. (2015). UN Global Action Programme and education for sustainable development: A critical appraisal of the evidence base. Discourse and Communication for Sustainable Education, 6, 5-20. doi: 10.1515/dcse-2015-000

Fernández-Berrocal, P., \& Ruiz, D. (2008). Emotional intelligence in education. Electronic Journal of Research in Educational Psychology, 15, 6(2), 421-436.

Ferreira, M., (2017). Guia para uma pedagogia diferenciada em contexto de sala de aula - Teoria, práticas e desafios [A guide to a differentiated pedagogy in the classroom - Theory, practices and challenges]. Coleção de Guias Educacionais. Lisboa: Coisas de Ler.

Gest, S., Welsh, J., \& Domitrovich, C. (2005). Behavioral predictors of changes in social relatedness and liking school in elementary school. Journal of School Psychology, 43, 281-301.

Ghorbani, S., Jafari, S., \& Sharifian, F. (2018). Learning to be: Teachers' competences and practical solutions: A step towards sustainable development. Journal of Teacher Education for Sustainability, 20(1), 20-45.

Goldstein, A., McGinnis, E., Sprafkin, R., Gershaw, N. J., \& Klein, P. (2011). Skill streaming the adolescent: A guide for teaching prosocial skills. Champaign, IL: Research Press.

Greenberg, M. T., Weissberg, R. P., O’Brien, M. U., Zins, J. E., Fredericks, L., Resnik, H., \& Elias, M. J. (2003). Enhancing school-based prevention and youth development through coordinated social and emotional learning. American Psychologist, 58, 466-474.

ISBE. (2003). Illinois learning standards. Science: Illinois State Board of Education. Retrieved from https://www.isbe.net/pages/social-emotional-learningstandards.aspx

Jennings, P. A., \& Greenberg, M. T. (2009). The prosocial classroom: Teacher social and emotional competence in relation to student and classroom outcomes. Review of Educational Research, 79, 491-525. 
Klem, A., \& Connell, J. (2004). Relationships matter: Linking teacher support to student engagement and achievement. Journal of School Health, 74, 262-273.

Leahy, S., Lyon, C., Thompson, M., \& Wiliam, D. (2005). Classroom assessment minute by minute, day by day. Educational Leadership, 63(3), 18-24.

Lemerise, E. A., \& Arsenio, W. F. (2000). An integrated model of emotion processes and cognition in social information processing. Child Development, 71, 107-118.

Machado, R., \& César, M. (2012). Trabalho colaborativo e representações sociais: Contributos para a promoção do sucesso escolar em matemática [Collaborative work and social representations: Contributions to the promotion of academic success on mathematics]. Interações, 20, 98-140.

Mahoney, J. L., Durlak, J. A., \& Weissberg, R. P. (2018). An update on social and emotional learning outcome research. Phi Delta Kappan, 100, 4, 18-23.

Martinsone, B. (2016). Social emotional learning: Implementation of sustainabilityoriented program in Latvia. Journal of Teacher Education for Sustainability, 18(1), 57-68.

Martinsone, B., \& Vilcina, S. (2017). Teachers' perceptions of sustainability of the social emotional learning program in Latvia: A focus group study. Journal of Teacher Education for Sustainability, 19(2), 5-20.

Nicol, D., \& Macfarlane-Dick, D. (2006). Formative assessment and self-regulated learning: A model and seven principles of good feedback practice. Studies in Higher Education, 31(2), 199-218.

O’Brien, M. U., \& Resnik, H. (2009). The Illinois social and emotional learning (SEL) standards: Leading the way for school and student success. Illinois Principal Association, 16(7), 2-5.

Organization for Economic Co-Operation and Development (OECD). (2013). Synergies for better learning: An international perspective on evaluation and assessment. Organisation for Economic Co-operation and Development.

Organization for Economic Co-Operation and Development (OECD). (2018). The Future of education and skills: Education 2030. Retrieved from https://www.oecd.org/ education/2030/E2030\%20Position\%20Paper\%20(05.04.2018).pdf

Payton, J., Weissberg, R. P., Durlak, J. A., Dymnicki, A. B., Taylor, R. D., Schellinger, K. B., \& Pachan, M. (2008). The positive impact of social and emotional learning for kindergarten to eighth-grade students: Findings from three scientific reviews. Chicago, IL: Collaborative for Academic, Social, and Emotional Learning.

Salite, I. (2008). Educational action research for sustainability: Constructing a vision for the future in teacher education. Journal of Teacher Education for Sustainability, 10, 5-16. doi: 10.2478/v10099-009-0021-6

Savitz-Romer, M., \& Bouffard, S. M. (2012). Ready, willing, and able: A developmental approach to college access and success. Cambridge, MA: Harvard Education Press.

Schutz, P. A., \& Pekrun, R. (2007). Emotion in education. San Diego, CA: Academic Press.

Sendziuk, P. (2010). Sink or swim? Improving students learning through feedback and self-assessment. International Journal of Teaching and Learning in Higher Education, 22(3), 320-330.

Shallcross, T. (2003). Cultural lessons about education for sustainable development and teacher education from a European project. Journal of Teacher Education and Training, 3, 3-14. 
Taylor, R. D., Oberle, E., Durlak, J. A., \& Weissberg, R. P. (2017). Promoting positive youth development through school-based social and emotional learning interventions: A meta-analysis of follow-up effects. Child Development, 88(4), 1156-1171.

Ulavere, P., \& Veisson, M. (2015). Values and values education in Estonian preschool child care institutions. Journal of Teacher Education for Sustainability, 17(2), 108124.

United Nations Educational, Scientific and Cultural Organization (UNESCO). (2014). Roadmap for implementing the Global Action Programme on education for sustainable development. Paris: UNESCO publishing.

UNESCO. (2019). Transforming Education Conference for Humanity (TECH), Vizag, India. Retrieved from https://mgiep.unesco.org/tech

United Nations. (2015). Transforming our world: The 2030 agenda for sustainable development. Retrieved from https://sustainabledevelopment.un.org/post2015/ transformingourworld

Vygotsky, L. S. (1962). Thought and language. Cambridge, MA: MIT Press.

Weissberg, R. P. (2019). Improving the social and emotional learning of millions of school children. Perspectives on Psychological Science, 14(1), 65-69.

WHO. (2015). World health statistics 2015. World Health Organization. Retrieved from https://apps.who.int/iris/handle/10665/170250.

Wiliam, D. (2011). Embedded formative assessment. Bloomington, IN: Solution Tree.

Zins, J. E., Bloodworth, M. R., Weissberg, R. P., \& Walberg, H. J. (2004). The scientific base linking social and emotional learning to school success. In Zins, J., Weissberg, R., Wang, M., \& Walberg, H. J. (Eds.), Building academic success on social and emotional learning: What does the research say? (pp. 3-22). New York, NY: Teachers College Press.

Correspondence concerning this paper should be addressed to Baiba Martinsone, Professor in Clinical psychology, University of Latvia, Imantas 7. linija 1, Riga, LV-1083, Latvia. Email: baiba.martinsone@lu.lv 